\title{
Frost resistance of seeds in Mediterranean oaks and the role of litter in the thermal protection of acorns
}

\author{
Jordán ESTESO-MARTíNEZ, Eustaquio GIL-PELEGRÍN* \\ Centro de Investigación y Tecnología Agroalimentaria de Aragón, Gobierno de Aragón, Aptdo 727, 50080 Zaragoza, Spain
}

(Received 19 March 2003; accepted 26 June 2003)

\begin{abstract}
The endogenous frost resistance of the seeds of four Mediterranean oaks (Quercus coccifera, Q. faginea, Q. ilex and Q. pyrenaica) with different leaf abscission phenology was tested. Thermal analysis and polyelectrolytes leakage methodologies were employed to establish lethal temperature thresholds. Results showed a higher frost resistance for evergreen species and lower for deciduous species in this decreasing order: $Q$. coccifera, $Q$. ilex, $Q$. faginea and $Q$. pyrenaica. The cover of leaf litter generated by deciduous species could be an isolating element which allowed seed survival under cold winter conditions to that species with a lower frost resistance. Differences in temperature above and below a leaf litter cover along a winter season were measured in a $Q$. faginea stand, in this sense the kind effect of leaf litter from a thermal point of view was proved.
\end{abstract}

frost resistance / leaf litter / polyelectrolytic leakage / Quercus / thermal analysis

Résumé - Résistance au froid des semences de chênes méditerranéens et rôle de la litière comme protecteur thermique des glands. On a testé la résistance intrinsèque à la gelée dans les semences de quatre espèces de chênes méditerranéens (Quercus coccifera, $Q$. faginea, $Q$. ilex et $Q$. pyrenaica) différents par la phénologie de l'abscission foliaire. Des méthodes d'analyse thermique et des mesures de fuite de polyélectrolytes ont été utilisées pour établir les températures létales. Les résultats montrent une meilleure résistance des espèces à feuilles persistantes dans l'ordre suivant $(Q$. coccifera, $Q$. ilex, $Q$. faginea, $Q$. pyrenaica $)$. La litière produite par les espèces à feuilles caduques en tant que possible protecteur thermique permettrait la survie des glands ayant une résistance intrinsèque insuffissante vis-à-vis des températures hivernales de la région. De plus, on a mesuré les différences de température en-dessous et dessous la litière pendant une période hivernale dans une forêt de Q. faginea. L'effet de la litière en tant que protecteur thermique a été confirmé.

analyse thermique / fuite de polyelectrolytes / litière / Quercus / résistance au froid

\section{INTRODUCTION}

Mediterranean climate is usually characterized by dry and warm summers and wet and mild winters $[16,17]$. However it shows regional variations which differ from this general pattern when considering their rainfall and temperature regimes [33, 41]. Broad inner areas of Iberian Peninsule present a continental variant of Mediterranean climate with dry and cold winters $[21,22]$. This winter conditions have been considered as critical periods for plant life [17, 33]. Some authors have even suggested that winter frosts could limit the geographical distribution of some Mediterranean oaks [15] operating negatively on some critical aspects of the physiology of seedlings [29, 35].

Less amount of information is available about the consequences of exposure to below zero temperature of oak seeds in natural conditions, although it is generally accepted that freezing processes are a constraint for regeneration [3, 5, 6, 13, 42, 43].
Available data about frost resistance of acorns are mostly related with long-term seed conservation. These studies focus on maximizing frost resistance of seeds at the expense of a reduction of their water content with no apparent losses in their viability [9, 14, 23, 24]. Ecological implications of these studies do not appear clearly since their experimental conditions are quite different from natural ones, however they show that acorns die at temperatures which are not exceptional during mediterranean winters in continental areas of the Iberian Peninsule [22]. In this way Boese et al. [9] fix a threshold for Quercus velutina around $-7^{\circ} \mathrm{C}$, other authors found for other species values around $-10^{\circ} \mathrm{C}[11,14,23,24]$.

It may be wondered now if thermal stress evitation mechanisms (supercooling) of seeds of certain mediterranean oak species are capable of guaranteeing the survival to winter conditions in their most continental areas of distribution. When certain temperature thresholds may be exceeded, the presence of a buffering

* Corresponding author: egilp@aragob.es 
element which gave enough thermal insulation would be critical for the regeneration of these species. In areas where some other isolating elements such as a snow cover [6, 27, 40, 45] are not common or show a short persistance [22] leaf litter may be supposed to be the main way of avoiding freeze stress due to its remarkable insulation capability [19].

The characteristic leaf phenology (semideciduous) of some oak species from mediterranean areas $[1,18]$ could ensure the presence of a leaf litter cover above the seeds that would improve their thermal microhabitat $[26,31]$. This improvement may not be so obvious for evergreen species which should be able to overcome winter frosts depending on other factors. In this way it is likely to believe that evergreen species produced seeds with a higher frost resistance.

The aims of this study are the comparison of lethal temperatures for seeds of mediterranean oak species with different leaf phenology (evergreen and semideciduous) so as the establishment of a relationship between this frost resistance and their ability to create a leaf litter cover which protected acorns during winter. The insulating role of leaf litter along a winter season in a $Q$. faginea stand in the Zaragoza province was monitored to check its insulation capability.

\section{MATERIALS AND METHODS}

\subsection{Plant material}

Seeds of $Q$. coccifera, $Q$. faginea and $Q$. ilex were collected during autumn of 1999 at several locations of Zaragoza province $(Q$. coccifera at Ejea de los Caballeros, Q. faginea at Daroca and $Q$. ilex at Paniza, Aladrén and Alfamén, these last three locations in a few kilometres range) except for $Q$. pyrenaica which were obtained from collections made by National Center of Forest Improvement "El Serranillo" (Ministerio de Medio Ambiente) at Serrania de Cuenca (Cuenca province). Seeds were selected and rehydrated by the floating method in tap water for $24 \mathrm{~h}$. Afterwards they were disinfected by inmersion in a $5 \%$ sodium hypochloride ( $40 \mathrm{~g} / \mathrm{L}$ of active chlorine) solution for $10 \mathrm{~min}$ and then carefully rinsed in tap water. Finally, seeds were stratified and treated with a common use fungicide (Pomarsol a.p Thiuram, Bayer) and then kept in a cold-storage room at $2{ }^{\circ} \mathrm{C}$ until the experiment started.

\subsection{Thermal analysis}

Temperature profiles were made in a modified commercial freezer, establishing cooling rates through an industrial controller (PMA Prozess-und Maschinen-Automation GmbH Mod. KS90, Germany) acting on a heating block with forced convection. Freezing was provided by the continuous performance of the freezer engine. Thermal homogeneity was achieved through a microfan system arranged inside of the chamber. This device provided a thermal stability of $\pm 0.1^{\circ} \mathrm{C}$ on set temperature along the whole thermal profile.

Methodology for thermal analysis was inspired by the one used by Boese [10]. However some modifications were necessary according to different recording methods and different theoretical approach. In our study we performed a thermal analysis instead of a differential thermal analysis and for temperature measurements two-wires PT100 sensors were used instead of thermistors. These modifications were necessary due to the features of the eight-channels digital recorders (A.B.I. Data Mod. VL100, Belgium) used in the experiment. In addition, no external ice nucleation source was used in any case.
Seeds used in the thermal analysis experiment were directly extracted from the cold-storage room, dried with a cloth and immediately set for the experiment. Moisture content was estimated previously to the experiment in 10 units batches of each species following the methodology suggested by Thomsen [48]. Very similar moisture contents were obtained for the four species $(46 \% \pm 2 \mathrm{SD}, n=10$ per species).

The PT100 sensor was firmly attached to the seed pericarp with adhesive tape and the whole wrapped in a piece of aluminium foil. Seeds were set in 10 units batches on a polyestirene platter inside of the freezer. Five reference wrapped sensors were set between each two seeds. Finally a bare sensor was set next to the samples to record chamber temperature. No external ice nucleation source was used in order to allow supercooling. The fixed cooling rate was of $1.5^{\circ} \mathrm{C} / \mathrm{h}$. This cooling rate reasonably matches with the ones recorded by us in the field (unpublished data) so as with the ones found in the literature [3, $10,12,14]$.

\subsection{Field temperature}

Temperatures in the field were recorded along six weeks (during January and February) above and below a leaf litter cover in four different points with homogeneous leaf litter thickness. Four fixing devices suitable for measurement at two different heights (above and below leaf litter) were designed. This devices consisted of a steel axis with a white lacquered aluminium dish at the top acting as a solarshield and two PT100 sensors attached at two different heights. The whole were fixed on the ground reconstructing as possible leaf litter structure after setting.

Average leaf litter thickness was estimated at $6 \mathrm{~cm}$ at the beginning of measurements. Natural leaf litter compression was allowed along recording period and upper sensor height was readjusted.

Sensors were connected to an eight-channels digital data recorder (A.B.I. Data Mod. VL100, Belgium) placed in a waterproof case and provided with a 30 days proved duration battery. With the aim of establishing correlations between our field measurements and a nearby weather station (Daroca $1^{\circ} 25^{\prime} \mathrm{W}, 41^{\circ} 07^{\prime} \mathrm{N}, 779 \mathrm{~m}$ a.s.l.) a third onechannel digital data recorder (Gemini Data Loggers Mod. Tinytalk II, London UK) provided with a PT100 sensor covered with a solar-shield was set at $1.5 \mathrm{~m}$ height above ground next to the other measurement points.

\subsection{Polyelectrolytic leakage}

The polyelectrolytic leakage analysis was planned with the aim of establishing a correspondence between ice formation inside the seed and tissue injury [10]. In this sense it was possible to attribute lethal consequences to ice formation.

In this experiment it was employed the same freezer as in the thermal analysis. Temperature profiles were adapted to experimental needs. This way, once established ice formation temperatures for the different species (from results of thermal analysis), five cooling-heating cycles (from $0{ }^{\circ} \mathrm{C}$ to $-3,-6,-9,-12$ and $-15^{\circ} \mathrm{C}$ respectively) were performed at the same cooling rate $\left(1.5^{\circ} \mathrm{C} / \mathrm{h}\right)$ for each species. Six seeds were used simultaneously in each cooling-heating process.

When cooling and heating process concluded, seeds were taken out from the chamber and immediately prepared for the experiment. A cotyledon section (width $2 \mathrm{~mm}$ ) of each seed was obtained using a two parallel scalpel blades assembly. The sample was gently rinsed in distilled water and sunk in $5 \mathrm{~cm}^{3}$ of distilled water in a glass tube. Full tubes were weighted in order to compensate subsequent evaporative water losses before the measurements. Tubes were sealed with Parafilm and samples were left at room temperature for $24 \mathrm{~h}$. A first measurement was performed to record the conductance of the polyelectrolytic leachate of the samples. 
After measurements samples were boiled for $10 \mathrm{~min}$ to achieve a total tissue degradation and left cool at room temperature for $2 \mathrm{~h}$. The conductance of boiled samples were registered after this period. Water losses were systematically compensated before each measurement. Equations for determining tissue injury rest on the ones proposed by Flint et al. [20]. As a basal leakage value it was employed a mean value ( $n=15$ per species) of undamaged samples of each species with the same characteristics as the ones used in the experiment.

A conductimeter (Conductimeter Basic 30, Crison Instruments S.A., Spain) was used for all the measurements. As a reference, an Lt50 value (temperature at which $50 \%$ of injury is reached) was obtained according to the sigmoid model obtained for each species.

\section{RESULTS}

\subsection{Frost resistance}

The thermal analysis performed on the seeds of the four studied species allowed to establish significant differences among them. Average freezing temperatures for the four species are shown in Figure 1. As a reference it has been considered the starting point of the exotherms as suggested in several studies $[10,12]$. Some freezing and exotherm profiles are shown in Figure 2.

It is remarkable the presence of an apparent high temperature exotherm a few degrees below zero, only in the deciduous species (Q. pyrenaica and $Q$. faginea). This fact may be similar to the one observed in other studies and it is attributable to some kind of extracellular freezing process.

All these results are consistent with the polyelectrolytes leakage analysis where Lt50 values arrange species in a very similar way, as shown in Figure 3.

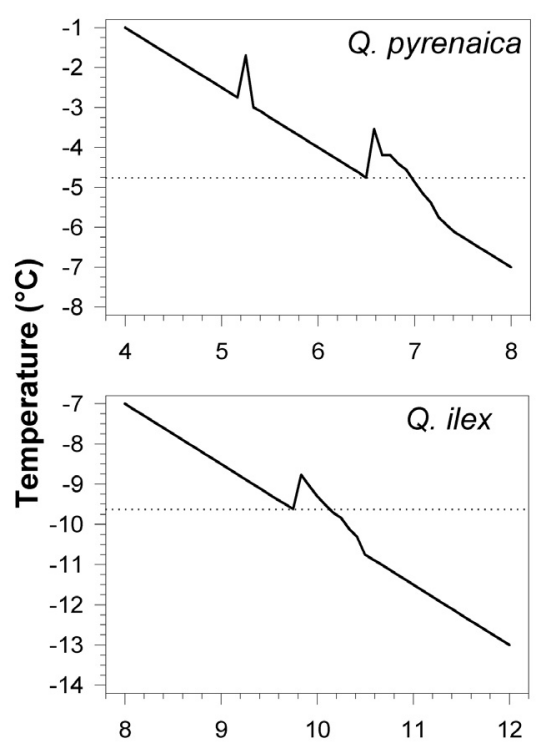

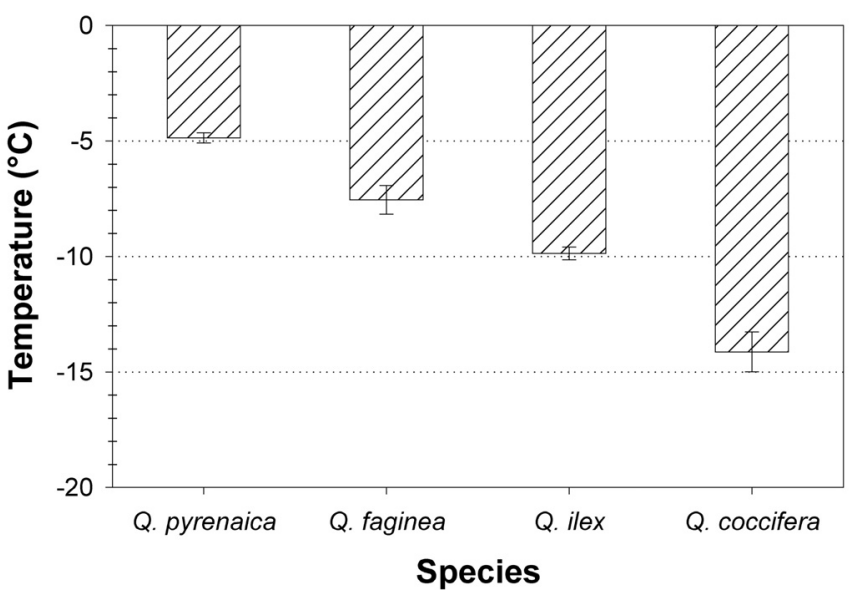

Figure 1. Average freezing temperature (starting point of exotherm) for the four Quercus species studied. Vertical bars represent SE of the mean ( $n=10$ per species).

\subsection{Long term climatic characterization}

Taking into account the available data from Daroca (Zaragoza) weather station which comprise the period from 1919 to 2000 (except for the period 1930-1942) it has been possible to establish a minimum temperatures probability distribution. Considered data are referred to the days between winter solstice and spring equinox. Probability distribution is shown in Figure 4.

Considering frost resistance values for other Quercus species acorns found in other papers [9-11, 14, 23, 24] so as the ones recorded by us, it can be observed that minimum temperatures

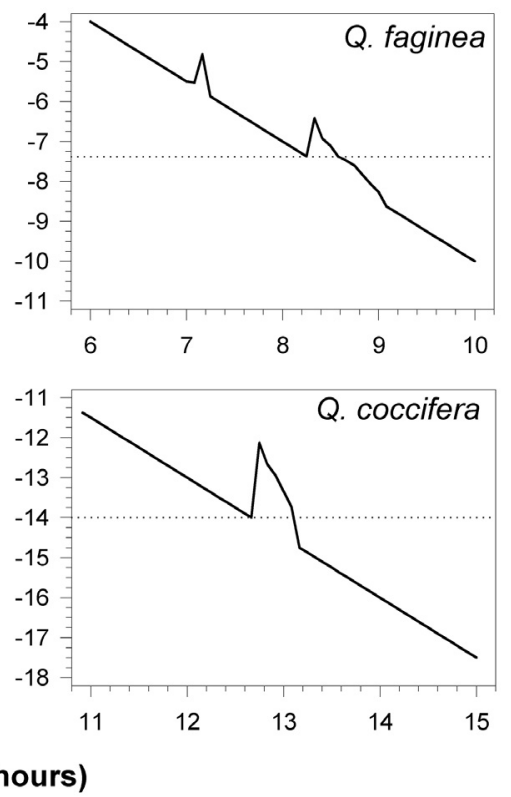

Figure 2. Typical freezing and exotherm profiles for the four species studied (in increasing order of frost resistance). Exotherms represented are obtained from mean values of starting point, width and duration of data obtained in thermal analysis. Time represents hours since experiment started. Cooling rate was $1.5^{\circ} \mathrm{C} / \mathrm{h}$. 
Table I. Absolute minimum, maximum and mean temperatures measured below and above a leaf litter cover in a Quercus faginea stand in the Zaragoza province (Spain).

\begin{tabular}{|c|c|c|c|c|c|c|}
\hline \multirow[b]{2}{*}{ Week } & \multicolumn{3}{|c|}{ Under leaf litter } & \multicolumn{3}{|c|}{ Over leaf litter } \\
\hline & $\begin{array}{l}\text { Absolute minimum } \\
{ }^{\circ} \mathrm{C}\end{array}$ & $\begin{array}{l}\text { Absolute maximum } \\
{ }^{\circ} \mathrm{C}\end{array}$ & $\stackrel{\text { Mean }}{{ }^{\circ} \mathrm{C}}$ & $\begin{array}{l}\text { Absolute minimum } \\
{ }^{\circ} \mathrm{C}\end{array}$ & $\begin{array}{l}\text { Absolute maximum } \\
{ }^{\circ} \mathrm{C}\end{array}$ & $\begin{array}{l}\text { Mean } \\
{ }^{\circ} \mathrm{C}\end{array}$ \\
\hline 1 & -3.50 & 3.50 & -0.70 & -13.30 & 16.45 & -3.17 \\
\hline 2 & -3.85 & 5.00 & -0.88 & -13.30 & 21.30 & -2.05 \\
\hline 3 & -1.30 & 9.80 & 3.10 & -9.80 & 23.10 & 3.38 \\
\hline 4 & 0.35 & 10.85 & 4.66 & -6.65 & 25.20 & 4.84 \\
\hline 5 & -0.70 & 12.25 & 4.21 & -9.45 & 28.00 & 4.02 \\
\hline 6 & -0.70 & 12.25 & 4.73 & -8.75 & 26.25 & 4.55 \\
\hline Mean & -1.62 & 8.94 & 2.52 & -10.21 & 23.38 & 1.93 \\
\hline
\end{tabular}

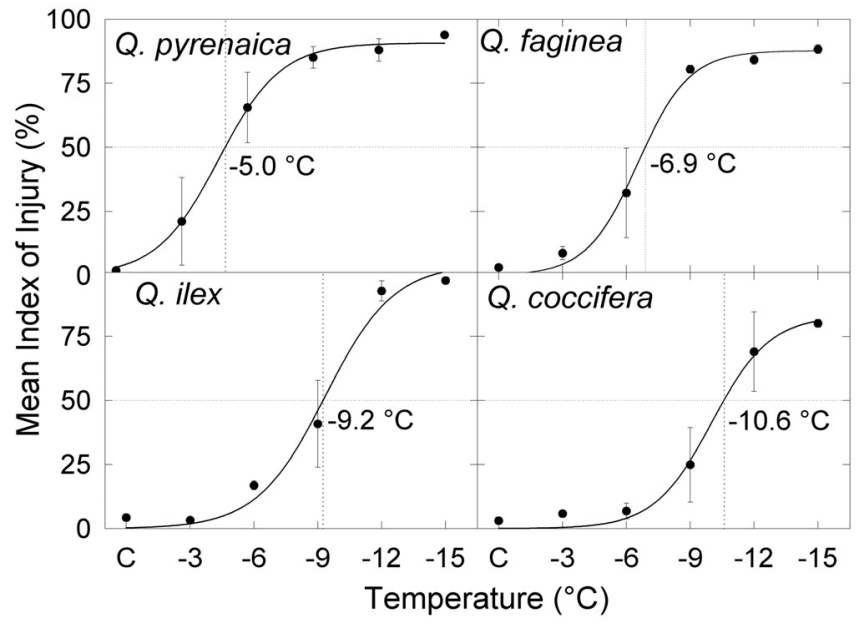

Figure 3. Mean index of injury obtained from polyelectrolitic leakage measurements at different temperatures for the four species studied. Vertical bars represent SE of the means ( $n=6$ per temperature). Dotted lines represent Lt50 values at the cutting point with sigmoids.

in our study area could exceed the resistance threshold of the seeds with relative frequency. Anyway since the exposure of the seeds to lethal temperatures is a critical process [9], even a low frequency of this phenomenon could be a limiting factor to seed survival.

Data recorded to establish the differences in temperature due to the presence of a leaf litter cover could register some of those critical periods. It is shown the efficiency of this cover as a thermal insulating material, maintaining minimum temperatures in a non lethal level even when $-13.3^{\circ} \mathrm{C}$ were registered a few centimetres above. This is shown in Table I.

\section{DISCUSSION}

Once again it has been possible to check the deviations from the typical conception of mediterranean climate that appear in the most continental areas of its influence. Night frost periods are in this way usual phenomena in these areas during winter.

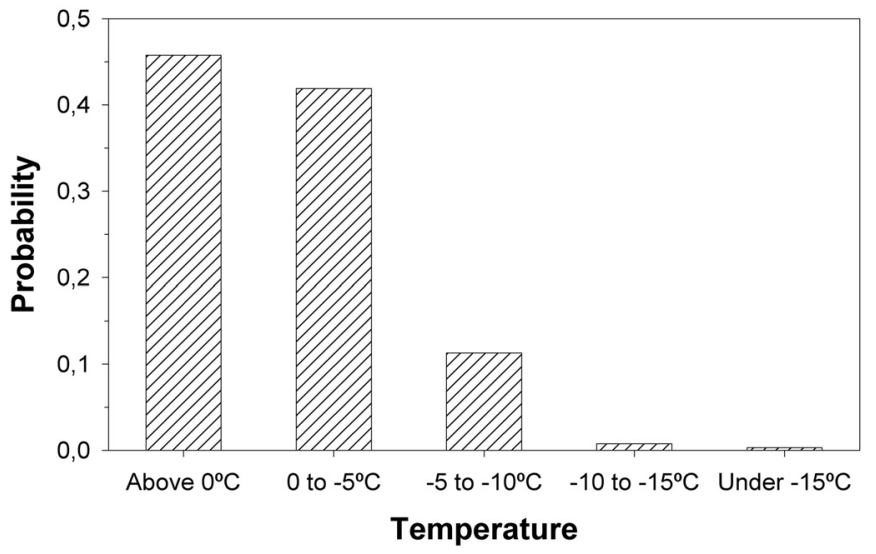

Figure 4. Probability distribution of minimum temperatures measured at Daroca weather station during the period from 1919 to 2000 (except for the period 1930-1942). Data are referred to the days between winter solstice and spring equinox.

Minimum temperatures reached occasionally during these periods could be a limiting factor for seed reproduction of some species with specially sensitive seeds such as Quercus species [9, 42-44].

Acorn survival after exposure to below zero temperatures has been tested in several previous papers. However, under extremely cold winters such as the ones found in continental areas of mediterranean climate, the range of frost resistances shown in those studies suggests the unfitness of endogenous mechanisms of stress evitation to overcome winter seasons in these areas. Our results confirm frost resistances that are consistent with previous studies. In this way, low temperatures could endanger seed regeneration for the studied species in our study area under present climatic conditions.

It is remarkable the arrangement of the threshold values of frost resistance obtained in both the thermal analysis and polyelectrolyte leakage (Figs. 2 and 3). It can be observed that seeds of evergreen species ( $Q$. coccifera and $Q$. ilex) appear to be more resistant to freeze stress. This is consistent with the most continental description of these species $[2,4]$. 
The role of leaf litter as an insulating material appears now as an important element in improving the microhabitat of seeds. This has been reported frequently in several papers [7, 25, 30$32,34,43,46]$ considering factors such as light, relative humidity, nutrient recycling, predation and temperature. However some other studies attribute to leaf litter negative effects that should not be obviated such as all allelopathic phenomena, pathogen proliferation or rooting difficulties between others [8, $19,28,37,47]$. Nevertheless some features of seeds and leaf litter of Quercus could balance partially these undesirable effects. In this way, Kostel-Hughes et al. [26] concluded that determined species with large seeds (Carya cordiformis, Quercus rubra and Quercus alba) perform indifferently or are even favoured by a thick cover of leaf litter. Lopez-Barrera and Gonzalez-Espinosa [30] observed that acorns fallen over oak leaf litter were progressively displacing downwards being finally covered by one o several layers of leaf litter. This phenomenon was not observed if acorns fell over a pine needle cover.

The main objective of this paper is to emphasize the key role of leaf litter in the survival of frost sensitive seeds such as Quercus acorns. Since endogenous frost resistance mechanisms of the acorns of the deciduous result inadequate to overcome winter conditions in continental areas under Mediterranean climate, it is possible to us to suggest that leaf litter not only creates a better regeneration conditions but the only way of avoiding freeze stress for the deciduous species studied. Endogenous frost resistance of evergreen species studied may be also exceeded in occasions. The phenology of abscission of some evergreen species has been studied resulting in a progressive loss of leaves along the year [18] or an early abscission in relation to seed dispersal $[38,39]$. In this way the litter covering effect achieved by evergreen species may be weakened in addition since leaf litter redistribution phenomena [36] could act extensively until acorn shedding. These results suggest the benefits of the generation and conservation of mixed stands of deciduous and evergreen oaks to encourage seedling recruitment under continental conditions.

Acknowledgements: This work was partially supported by a postgraduate INIA (Instituto Nacional de Investigación y Tecnología Agraria y Alimentaria) grant to the first author.

\section{REFERENCES}

[1] Abadía A., Gil E., Morales F., Montañés L., Montserrat G., Abadía J., Marcescence and senescence in a submediterranean oak (Quercus subpyrenaica E.H. del Villar). Photosynthetic characteristics and nutrient composition, Plant Cell Environ. 19 (1996) 685-694.

[2] Allué-Andrade J.L., Atlas fitoclimático de España. Taxonomías. MAPA, INIA, Colección Monografías INIA, 69, Madrid, 1990.

[3] Aizen M.A., Woodcock H., Effects of acorn size on seedling survival and growth in Quercus rubra following simulating spring freeze, Can. J. Bot. 74 (1996) 308-314.

[4] Amaral-Franco J., Quercus L., in: Servicio de Publicaciones del CSIC, Flora Ibérica, Vol. 2, Madrid, 1990.

[5] Aussenac G., Étude des gelées tardives en relation avec les problèmes de reboisement, Ann. Sci. For. 30 (1973) 141-155.

[6] Aussenac G., Étude des relations climat - régénération naturelle de chêne dans la région de Nancy de 1865 à 1972, Rev. For. Fr. XXVII (1975) 37-39.
[7] Barrett L.I., Influence of leaf litter on the germination and early survival of chestnut oak, Quercus montana Willd., Ecology 3 (1931) 476-484.

[8] Beatty S.W., Sholes O.D.V., Leaf litter effect on plant species composition of deciduous forest treefall pits, Can. J. For. Res. 18 (1988) 553-559.

[9] Boese S.R., George M.F., Mitchell R.J., Martin U., McQuilkin R.A., Physical aspects of freezing in black oak acorns, Proceedings of the Fifth Central Hardwood Forest Conference, Urbana-Champaign, Illinois, USA-April 15-17, 1985, pp. 222-227.

[10] Boese S.R., Physical aspects of freezing in black oak acorns and selected pine seeds, Thesis, University of Missouri-Columbia, 1986.

[11] Bonner F.T., Storing red oak acorns, Tree Pl. Notes 24 (1973) 12-13.

[12] Boorse G.C., Bosma T.L., Meyer A.C., Ewers F.W., Davis S.D., Comparative methods of estimating freezing temperatures and freezing injury in leaves of chaparral shrubs, Int. J. Plant Sci. 159 (1998) 513-521.

[13] Burke M.J., Gusta L.V., Quamme H.A., Weiser C.J., Li P.H., Freezing and injury in plants, Ann. Rev. Plant Physiol. 27 (1976) 507-528

[14] Chmielarz P., Odpornosc mrozowa zoledzi debu szypulkowego (Quercus robur L.) o wilgotnosci 42\%, Sylwan 8 (1996) 33-41.

[15] Cochard H., Tyree M.T., Xylem disfunction in Quercus vessel sizes, tyloses, cavitation and seasonal changes in embolism, Tree Physiol. 6 (1990) 393-407.

[16] DiCastri F., Mooney H.A., Mediterranean type ecosystems. Origins and structure, Springer-Verlag, Berlin, 1973.

[17] DiCastri F., Mediterranean-type shrublands of the world in: DiCastri F., Goodall D.W., Specht R.L. (Eds.), Mediterranean-type shrublands, Elsevier, Amsterdam, 1981, pp. 1-52.

[18] Escudero A., DelArco J.M., Ecological significance of the phenology of leaf abscission, Oikos 49 (1987) 11-14.

[19] Facelli J.M., Pickett S.T.A., Plant litter: Its dynamics and effects on plant community structure, Bot. Rev. 57 (1991) 1-32.

[20] Flint HL., Boyce B.R., Beattie D.J., Index of injury - A useful expression of freezing injury to plant tissues as determined by the electrolytic method, Can. J. Plant Sci. 47 (1967) 229-230.

[21] Font-Tullot I., Climatología de España y Portugal, INM, Madrid, 1983.

[22] Font-Tullot I., Historia del clima en España, INM, Madrid, 1988.

[23] Guthke J., Langzeitlagerung von Eichensaatgut. Probleme und Moeglichkeiten, Thesis, Hannover Universitat, 1993.

[24] Guthke J., Spethmann W., Physiological and pathological aspects of long-term storage of acorns, Ann. Sci. For. 50 (Suppl. 1) (1993) 384s-387s.

[25] Jones E.W., Biological flora of the British Isles: Quercus L., J. Ecol. 47 (1959) 169-222.

[26] Kostel-Hughes F., Young T.P., Carreiro M.M., Forest leaf litter quantity and seedling occurrence along an urban-rural gradient, Urban Ecosystems 2 (1998) 263-278.

[27] Larcher W., Physiological plant ecology, Springer-Verlag, New York, 1995.

[28] Li J., Romane F., Holm oak (Quercus ilex L.) coppice dynamics in southern France: The germination stage, in: Song Y., Dierschke H., Wang X. (Eds.), Applied vegetation ecology, East China Normal University Press, Shangai, China, 1994, pp. 122-127.

[29] LoGullo M.A., Salleo S., Different vulnerabilities of Quercus ilex L. to freeze and summer drought-induced xilem embolism: an ecological interpretation, Plant Cell Environ. 16 (1993) 511-519.

[30] López-Barrera F., González-Espinosa M., Influence of litter on emergence and early growth of Quercus rugosa: a laboratory study, New For. 21 (2001) 59-70.

[31] MacKinney A.L., Effects of forest litter on soil temperature and soil freezing in autumn and winter, Ecology 10 (1929) 313-321.

[32] Merino O., Martín-Vicente A., Producción de hojarasca en dos formaciones del SW Español, Lagascalia 15 (extra) (1988) 535-540. 
[33] Mitrakos K., A theory for Mediterranean plant life, Acta Oecol. 1 (1980) 245-252.

[34] Molofsky J., Augspurger C.K., The effect of leaf litter on early seedling establishment in a tropical forest, Ecology 73 (1992) 68-77.

[35] Nardini A., Salleo S., Lo Gullo M.A., Pitt F., Different responses to drought and freeze stress of Quercus ilex L., growing along a latitudinal gradient, Plant Ecol. 148 (2000) 139-147.

[36] Orndorff K.A., Lang G.E., Leaf litter redistribution in a West Virginia hardwood forest, J. Ecol. 69 (1981) 225-235.

[37] Peterson C.J., Facelli J.M., Contrasting germination and seedling growth of Betula alleghaniensis and Rhus typhina subjected to various amounts and types of plant litter, Am. J. Bot. 79 (1992) 1209-1216.

[38] Pérez LaTorre A.V., Cabezudo B., Use of monocharacteristic growth forms and phenological phases to describe and differentiate plant communities in Mediterranean-type ecosystems, Plant Ecol. 161 (2002) 231-249.

[39] Pérez LaTorre A.V., Cabezudo B., Nieto-Caldera J.M., Navarro T., Caracterización fenológica y ecomorfológica de alcornocales andaluces (Málaga, España), Anales Jard. Bot. Madrid 54 (1996) 554-560.

[40] Rixen C., Stoeckli V., Huovinen C., Huovinen K., The phenology of four subalpine herbs in relation to snow cover characteristics, in IAHS publ., Soil-Vegetation-Atmosphere transfer schemes and large-scale hydrological models, IAHS publ. 270 (2001) 359-362.
[41] Rodó X., Comín F., Fluctuaciones del clima mediterráneo. Conexiones globales y consecuencias regionales, in: Zamora R., Pugnaire F.I (Eds.), Ecosistemas Mediterráneos, analisis funcional, CSIC, Madrid, Spain, 2001, pp. 1-35.

[42] Sakai A., Larcher W., Frost survival of plants. Responses and adaptation to freezing stress, SpringerVerlag, New York (1987).

[43] Shaw M.W., Factors affecting the natural regeneration of sessile oak (Quercus petraea) in North Wales. I and II, J. Ecol. 56 (1968) 565-583, 647-660.

[44] Stanwood P.C., Bass L.N., Ultracold preservation of seed germplasm, in: Li P.H., Sakai A. (Eds.), Plant cold hardiness and freezing stress: Mechanisms and crop implications, Vol. 1, Academic Press, New York, 1978.

[45] Stoeckli V., Rixen C., Characteristics of artificial snow and its effects on vegetation, in: Conf. Proceedings of the Int. Snow Science Workshop, Big Sky, Montana, USA, October 1-6, 2000.

[46] Sydes C., Grime J.P., Effects of tree leaf litter on herbaceous vegetation in deciduous woodland. I and II, J. Ecol 69 (1991) 237-248, 249-262.

[47] Tao D.L., Xu Z.B., Li X., Effect of litter layer on natural regeneration of companion tree species in the Korean pine forest, Environ. Exp. Bot. 27 (1987) 53-65.

[48] Thomsen K., Handling of desiccation and temperature sensitive tree seeds. DFSC Series of Technical Notes. TN56, Danida Forest Seed Centre, Humlebaek, Denmark, 2000. 